\title{
Litigating Racial Profiling: The Use of Statistical Data
}

Tamar Hopkins PhD candidate, University of New South Wales, NSW, Australia

\begin{abstract}
The use of statistical data to prove racial discrimination by police in individual cases is relatively novel in Australia. Based on a survey of international strategies, this article argues that statistical and social science data can play three critical evidential roles in litigation. Firstly, it can form part of the social context evidence used to influence the inferences that can be drawn from other evidence led in a case. Secondly it can influence the cogency of the evidence required for claimants to meet the standard of proof, and thirdly, it can be used to shift the burden of proof. Using these evidential methods, evidence of institutional racism can be used to assist in making findings of discrimination in individual cases. This article speculates on the role that statistics could have played in the Haile-Michael race discrimination claim that settled in 2013, and in the 2019 inquest into the death of Tanya Day.
\end{abstract}

Keywords - Racial profiling, statistical evidence, race discrimination, data collection

Acknowledgments: I would like to thank Victoria Sentas, Amanda Porter, Anthony Hopkins, Paco Perales, Andrew Hopkins and the anonymous reviewers for their comments and suggestions on the drafts.

Disclosure statement: No potential conflict of interest was reported by the author. Along with Peter Seidel from Arnold Bloch Leibler, Tamar Hopkins was one of the solicitors for the applicants in the Haile-Michael proceedings.

License: This work is under Attribution-NonCommercial-ShareAlike 4.0 International (CC BY-NC-SA 4.0)

https://creativecommons.org/licenses/by-nc-sa/4.0/

Suggested citation: Hopkins, T. (2021) “Litigating Racial Profiling: The Use of Statistical Data." Law in Context, 37 (2): 37-53, DOI: https://doi.org/10.26826/law-in-context.v37i2.155

\section{Summary}

1. Introduction

2. Institutional and individual racism

3. The Evidential Use of Statistics in Litigation

3.1 The use of statistics in establishing the social context

3.2 The use of statistics in determining the standard of proof

3.3 The use of statistics to shift the burden of proof

3.3.1 The use of statistical evidence to shift the burden of proof in the UK

3.3.2 The use of statistics to shift the burden of proof in the US

3.3.3 The use of statistics to shift the burden of proof in Canada

4. Application to Australian case

4.1 Haile-Michael

4.2 Tanya Day

5. Conclusion

6. References 


\section{INTRODUCTION}

On 5 December 2017, Yorta Yorta grandmother and community leader, Tanya Day, was arrested by members of Victoria Police for being drunk in a public place. While in custody, Tanya experienced a lethal head injury and died some days afterwards. In an interlocutory ruling before the inquest into her death the Coroner Anna English agreed that witnesses could be asked about whether racism played a role in their decisionmaking. ${ }^{1}$ Tanya's children produced evidence that 9 per cent of women recorded as offenders for the offence of being drunk in public by Victoria Police were Aboriginal women. Aboriginal women make up only 0.9 per cent of the Victorian population. ${ }^{2}$ Furthermore 88 per cent of Aboriginal women charged with being drunk were taken into custody to the police station, as compared with 77 per cent of non-Indigenous women charged with the same offence. ${ }^{3}$ In her interlocutory ruling, Coroner English accepted that statistical data "provides a reasonable basis for me to assess whether direct or indirect racism played a role in determining the facts comprising the circumstances of Ms Day's death". ${ }^{4}$ However, she also concluded that "[Statistical evidence] cannot have an evidentiary or causal role in the conclusions I reach in my consideration of the evidence." 5 I have reconciled the Coroner's otherwise contradictory rulings to mean that while statistical evidence can provide evidence of systemic racism, it can have no evidentiary role in determining the existence of racial discrimination in a specific instance.

Coroner English's refusal to accept the role of statistical data in drawing factual inferences about causation in specific instances reflects the novelty of using statistical or other social science data to prove racial discrimination in Australia to date. However, where statistical data is relevant to an issue under consideration, I argue that there is no logical reason to exclude it as evidence capable of supporting a decision on the causative role of racial discrimination in a particular instance. Legal findings of fact, including causation, are never definitive, but concern probabilities. A finding 'on the balance of probabilities' is a finding that one fact is more probable than another. Drawing inferences based on probabilities lies at the heart of statistical analysis as well as legal decision-making (Burtis et al 2017).

The role of statistics in proving racial discrimination was also an issue in Haile-Michael v Konstantindis VID 969/2010, a racial profiling claim under the Racial Discrimination Act 1975 (Cth) (the 'RDA'). In this case, six African-Australian youth claimed that the police had engaged in unlawful racial discrimination in stopping, searching and, at times, using force to arrest them. They were able to obtain statistically significant evidence that the police disproportionately stopped African youth in the area for field contacts (Hopkins 2021). However, the settlement of this case on 18 February 2013 left the issue of how these statistics may have been used in this case unresolved.

The intention of this article is to analyse the judicial consideration of racial discrimination statistics in cases against the police and in doing so, provide guidance to Australian legal practitioners in considering the use of statistical data.

This article firstly examines the difference between institutional racism and individual discrimination in law. I then examine the definition of racial discrimination in the $R D A$. Next, I explore the strategies for proving racial discrimination employed by the European Court of Human Rights, and in other jurisdictions including the United States District Court for Southern New York, the Canadian Supreme Court, the Ontario Court of Justice and in the United Kingdom (UK). Finally, I return to the evidential use that could have been made of

\footnotetext{
${ }^{1}$ Ruling on Application Regarding Scope of the Inquest Tanya Day (Coroners Court of Victoria, Melbourne, 25 June 2019 ) 82 , 83.

${ }^{2}$ Finding into the death of Tanya Day (Coroners Court of Victoria, 9 April 2020) 30.

${ }^{3}$ Ruling on Application Regarding Scope of the Inquest Tanya Day (n 1) 30.

${ }^{4}$ Ibid 73.

${ }^{5}$ Ibid 82.
} 
statistics gathered in the two key Australian cases mentioned above: the Haile-Michael claim and Tanya Day inquest.

\section{INSTITUTIONAL AND INDIVIDUAL RACISM}

Institutional or systemic racism is concerned with the discriminatory impacts of institutional policies and practices on racial minorities, regardless of intention (Carmichael and Hamilton 1967; Taylor 2016; BonillaSilva 2014). Courts and inquiries have made findings of institutional racism against police. For example, the Metropolitan Police in England were found to be institutionally racist in the 1999 Stephen Lawrence Inquiry (Marlow and Loveday 2000). The collapse of the police construction of events exposed institutional racism as the only plausible explanation for the police failure to adequately investigate Black school-student Stephen Lawrence's death (Hall 1999, 187). Judges have also made findings of institutional racism using other sources of social knowledge. For example, along with other evidence, clear racial disparities in statistical data about who was stopped and frisked enabled the Court in Floyd $v$ The City of New York (2013) to find that the stop and frisk program run by the New York Police department was institutionally racist. ${ }^{6}$

In Australia, recent data from the Western Australian Police (WAP)'s research unit reveals that in 2017 2018, in regional areas, Aboriginal drivers were 18 per cent less likely to attract a camera initiated fine than other drivers, but 4.2 times more likely to get an on-thespot fine (Barnes 2019, p. 9). The availability of this kind of data in Australia is rare. It became public in this instance through a freedom of information request by the Guardian newspaper. The WAP research unit states, "These findings are consistent with a notable ethnic disparity in police-initiated traffic enforcement but by no means provide conclusive evidence that deliberate bias exists" (Barnes 2019, p. 10). Because the concept of institutional racism does not require proof of deliberately racist decision-making, the WAP data disparities are sufficient to make a prima facie claim of institutional racism by the WA police in issuing on-the-spot fines. While the WAP data provides evidence of institutional racism, the question for this article is whether such data could be used in court to provide evidence of racial discrimination in individual cases. This question remains unanswered in Australia.

Australia's $R D A$ is concerned with two forms of racial discrimination. The first form in section 9(1) concerns direct racism: the discriminatory acts or omissions of one individual towards another. The second in s 9(1A) concerns indirect racism through the imposition by one individual on another of unreasonable racially discriminatory terms, conditions or requirements. ${ }^{7}$ In both cases, employers can be vicariously liable and proof of intent is not required. Similar to the broader concept of institutional racism, it is sufficient to prove that the effect or impact of a person's conduct or omission has produced a discriminatory outcome. Relevant parts of Section 9(1) of the RDA are as follows:

(1) It is unlawful for a person to do any act involving a distinction, exclusion, restriction or preference based on race, colour, descent or national or ethnic origin which has the purpose or effect of nullifying or impairing the recognition, enjoyment or exercise, on an equal footing, of any human right or fundamental freedom in the political, economic, social, cultural or any other field of public life. [emphasis added]

Section 9(1) of the RDA makes it unlawful for a person to do any act based on race that impairs a person's human rights. Section $9(1 \mathrm{~A})$ makes it unlawful for a person to unreasonably impose a condition, term or requirement on a person, that is not, or cannot be complied with, which impairs the human rights of people of that race. Relevant rights involved in racial profiling includes freedom of movement under the Convention on

\footnotetext{
${ }^{6}$ Floyd $v$ The City of New York, 959 F.Supp.2d 540, 2013 WL 4046209.

7 See (Sentas, 2014) where the author argues indirect racism is a buried form of institutional discrimination.
} 
the Elimination of Racial Discrimination. ${ }^{8}$ They also include equality before the law, privacy, liberty, humane treatment in custody, freedom from arbitrary detention and freedom from ill-treatment ${ }^{9}$ under state-based human rights legislation and the International Covenant on Civil and Political Rights. ${ }^{10}$

In s 9(1) of the $R D A$, the phrase 'based on race' invokes a trigger definition for racial discrimination (Siu 2017, p. 11). Section 18 of the RDA clarifies that the act could be based on one or more reasons, so long as one of those reasons is race. Consequently, for the purpose of s 9(1) it is necessary to prove that the actions of police were, in part, based on race. In Wotton v Queensland, Mortimer J usefully clarifies that, "it is well-established that the phrase "based on race" in s 9 does not imply any causal requirement but connotes that the act involving the distinction, exclusion, restriction, or preference be done, or undertaken, by reference to race." 11

In contrast, the definition of 'based on race' contained s $9(1 \mathrm{~A})$ is not a trigger definition. Here, 'based on race' means "an unreasonable condition or requirement", "that is not or cannot be complied with", that disadvantages people of "the same race" as the applicant. This second definition remains largely unexplored in Australian case law, but its language directly invokes evidence of systemic racial disparities. ${ }^{12}$

For the purposes of s 9(1) of the $R D A$, there are three interrelated common law devises that make statistical evidence of institutional racism relevant to a claim that individual police acts or omissions are 'based on race'. The first concerns its use in understanding the social context of the evidence being led. The second relates to the way statistical evidence impacts the standard of proof. The third concerns the use of statistical evidence in creating a prima facie case of racial discrimination.

Statistical data is a type of social science evidence. Consequently, the following paragraphs may be relevant to many forms of social science evidence. Where possible I investigate the specific use of statistics in court proceedings. While each of the cases I discuss concern specific legislation, it is the evidentiary principles they illuminate that contain insight and relevance across jurisdictions.

\section{THE EVIDENTIAL USE OF STATISTICS IN LITIGA- TION}

\subsection{THE USE OF STATISTICS IN ESTABLISHING THE SO- CIAL CONTEXT}

One of the most critical uses of statistics and other forms of social science data is to provide the social context for a court to make sense of issues before it. While social context evidence is necessary for courts to assess the role of racism in cases before them, Canadian courts have also found it is essential for ensuring impartial decision-making. In $R v S(D S)$, a case where the trial judge used social context evidence to assess the credibility and probability of the conflicting stories provided by a Black youth and a police officer, two judges in the Supreme Court of Canada stated:

[A judge] must be taken to possess knowledge of the local population and its racial dynamics, including the existence in the community of a history of widespread and systemic discrimination against black and aboriginal people, and highprofile clashes between the police and the visible minority population over policing issues. ${ }^{13}$

\footnotetext{
${ }^{8}$ UN General Assembly, International Convention on the Elimination of All Forms of Racial Discrimination, 21 December 1965, United Nations, Treaty Series, vol. 660, p. 195, available at: http://www.refworld.org/docid/3ae6b3940.html [accessed 3 October 2018], Art 5, and Charter of Human Rights and Responsibilities Act 2006 (Vic), s12.

${ }^{9}$ See for example s10, 13, 16, 21, 22 of Charter of Human Rights and Responsibilities Act 2006 (Vic).

${ }^{10}$ UN General Assembly, International Covenant on Civil and Political Rights, 16 December 1966, United Nations, Treaty Series, vol. 999, p. 171

11 Wotton v The State of Queensland (No 5) [2016] FCA 1457, 551.

12 Thank you to Victoria Sentas for this observation.

${ }^{13} R v S(R D)$ [1997] 3 SCR 484508.
} 
In this case, the social context evidence provided context for why the Black youth's account provided a better, more credible explanation for the events that unfolded. An example of how statistical data can be used to understand the facts of a case appears in Nassiah $v$ Peel where the Human Rights Tribunal of Ontario stated:

The fact that racial profiling occurs in policing in the Toronto Region and likely occurs in the Peel Region does not answer the question whether Ms. Nassiah was discriminated against in this particular case. However, the evidence is useful in identifying factors or clues which point toward racial profiling/discrimination which might otherwise appear neutral if taken in isolation and without an awareness of the phenomenon of racial profiling. ${ }^{14}$

In this case statistical evidence of racial profiling was used to understand and contextualise the police investigation of an African Canadian women suspected of theft. Agarwal, Lalani and Boutilier explain that the relevance of this evidence may need to be established by linking it to the material issues (Agarwal et al 2018, p. 38) and through an explanation of "how the pieces of evidence taken together support inferences of discrimination" (Agarwal et al 2018, p. 55).

Social context evidence is the tool that enables courts to conclude whether police conduct corresponds with racial profiling. The 'correspondence test' (Tanovich 2018) is set out in the Ontario Court of Appeal case $R v$ Brown. ${ }^{15}$ In this case, police pulled over Black man Dee Brown who was driving a sports car. The Court stated:

A racial profiling claim could rarely be proven by direct evidence. This would involve an admission by a police officer that he or she was influenced by racial stereotypes in the exercise of his or her discretion to stop a motorist. Accord- ingly, if racial profiling is to be proven, it must be done by inference drawn from circumstantial evidence. Where the evidence shows that the circumstances relating to a detention correspond to the phenomenon of racial profiling and provide a basis for the court to infer that the police officer is lying about why he or she singled out the accused person for attention, the record is then capable of supporting a finding that the stop was based on racial profiling. [emphasis added].

The circumstances that have been found to correspond to racial profiling are frequently those where police actions are unnecessary, unusual, unjustified, excessive and/or unlawful (Tanovich 2018). Acts such as pulling up to a car to look in the window before stopping a vehicle ( $R v$ Brown) or the questioning of passengers can be sufficient to ground a finding of racial profiling. However, "the presence of reasonable grounds does not disprove racial profiling." 16 Implicit in the correspondence test set out above is that judges understand the way the social context of racism in society frames the other circumstantial evidence provided to the court. Where judges are not familiar with this social context, statistical and/or other social science evidence will be needed to permit judges to understand how the evidence in front of them corresponds with racial profiling.

\subsection{THE USE OF STATISTICS IN DETERMINING THE STANDARD OF PROOF}

Underpinning the ability of decision-makers to make a finding 'on the balance of probabilities' that police conduct corresponds with racial profiling is an understanding of how the standard of proof operates in these cases. In Department of Health $v$ Arumugan the Victorian $\mathrm{Su}-$ preme Court held that "racial discrimination is a serious matter which is not lightly to be inferred."17 This statement has implications about the cogency of the evidence required to prove discrimination. It implies that plaintiffs will need forceful evidence before a positive finding

\footnotetext{
${ }^{14}$ Nassiah v. Peel (Regional Municipality) Services Board, 2007 HRTO 14 [130]-[131].

${ }^{15} R$ v Brown [2003] OJ No 1251 (2003).

${ }^{16} R v$ Dudhi, 2019 ONCA 665 (Ontario Court of Appeal, 14 June 2017) 84.

${ }^{17}$ [1988] VR 319, 331
} 
of fact can be made. It draws on Briginshaw $v$ Briginshaw ${ }^{18}$ in which Dixon J concluded that when applicants make allegations of improbable conduct, courts should proceed cautiously in determining that the civil standard of proof has been satisfied (de Plevitz, 2003, p. 308). In the 2015 Western Australian RDA case Ejueyitsi ${ }^{19}$ His Honour Lucev J quotes from the High Court in Neat Holding Pty Ltd:

[There is a] conventional perception that members of our society do not ordinarily engage in fraudulent or criminal conduct and a judicial approach that a court should not likely make a finding that, on the balance of probabilities, a party to civil litigation has been guilty of such conduct. ${ }^{20}$ [emphasis added]

Neat Holdings clarifies that judges should not easily make findings in relation to behaviour that is out of the ordinary. Where the Courts in Ejueyitsi $v$ Commissioner of Police (Western Australia) (No 2) and Arumugan go wrong, however, is in concluding that racial discrimination is necessarily 'out of the ordinary' or 'improbable'. To the contrary, in the context of policing, social context evidence now exists in many jurisdictions establishing that race is a standard operational tool in determining who police will target for attention. Consequently, from a Briginshaw perspective, racial discrimination is probable not improbable.

Statistical and social science evidence has demonstrated that racial discrimination is a normal part of everyday policing in three ways. Firstly, research based on close observations of police in practice (Dixon 1998, 185; Van Maanen 1978; Skolnick and Fyfe 1993; McConville et al 1991; Stuart 2016) has shown that race plays a significant part in who police scrutinise and the formation of police suspicion. This evidence shows that race and racialised proxies are routine short-cuts for police in determining who they will pay attention to and how they will be treated. Secondly, there is evidence that racialised ${ }^{21}$ people are frequently the subject of unjustified and disproportionate inclusion in police databases (Williams 2018; Sentas and Pandolfini 2017; Weber 2020). Thirdly we know from statistical evidence in jurisdictions where police data is made public, including in the policing of COVID-19 regulations (Faruqi 2020; Boon-Kuo 2020, p.80), that racialised people, Black and Indigenous people in particular, are more likely to be policed than White people, and that police post-stop conduct towards them is likely to be more extreme (Epp et al 2014; Baumgartner et al 2018; Gordon 2012; Shiner 2018; Shiner and Thornbury 2019; Dunn and Shames 2019).

Because statistical and social science evidence shows that racial discrimination is normalised in police activities, the evidence required to meet the standard of proof (on the balance of probabilities) should not be particularly burdensome. Statistical evidence demonstrates that racial profiling from a Briginshaw perspective is probable, not improbable. Consequently, depending on the circumstances of the case, the inference that a stop of a racialised person is based on race can be relatively routine. ${ }^{22}$

The difficulties for practitioners in accepting the ease with which the standard of proof in RDA claims can be met relate, in part, to the moral power of racial discrimination allegations. Mortimer J in Wotton states that, "to allege that individuals performing public functions and exercising public powers did so on the basis of race is to make an allegation that reflects poorly upon those individuals." 23 While acting on the basis of race

\footnotetext{
${ }^{18}$ Briginshaw v Briginshaw (1938) 60 CLR 336 (30 June 1938).

${ }^{19}$ Ejueyitsi v Commissioner of Police (Western Australia) (No 2) [2015] FCCA 494.

20 Neat Holdings Pty Ltd v Karajan Holdings Pty Ltd (1992) 110 ALR 449 at 449-450 per Mascon CJ, Brennan, Deane and Gaudron JJ.

${ }^{21}$ I use the term 'racialised' to mean people to whom the Anglo-saxon White gaze has supplied a racial identity and sees as 'other'. White people are also racialised, but due to White supremacy, they frequently don't see it this way. I include here all non-White racialised groups including Indigenous and other ethnic and racial minorities.

${ }^{22}$ See Barnes v Northern Territory Police \& Anor [2013] FCCA 30.

${ }^{23}$ Wotton $v$ The State of Queensland (No 5) [2016] FCA 1457, 114.
} 
does reflect poorly on individuals it is the institutional acceptability of such practices where responsibility lies. The gravity of the allegation is an aspect of the Briginshaw test, but so too is the nature of the subject matter of the proceeding. ${ }^{24}$ With proof of intent not required in RDA claims, the court's role in deciding the likelihood of an event taking place is more fundamentally about its probability than its gravity.

\subsection{THE USE OF STATISTICS TO SHIFT THE BURDEN OF PROOF}

Statistical evidence does not only have implications for the standard of proof. As we will see now, it has implications for the burden of proof as well. The European Court of Human Rights has concluded in a number of cases that relevant and significant statistical evidence of ongoing discrimination can be used to create a rebuttable presumption that conduct was based on race/ethnicity in individual cases. In D.H. v. The Czech Republic, Grand Chamber Judgment of 13 November 2007, the Court stated:

The Court considers that when it comes to assessing the impact of a measure or practice on an individual or group, statistics which appear on critical examination to be reliable and significant will be sufficient to constitute the prima facie evidence the applicant is required to produce....Where an applicant alleging indirect discrimination thus establishes a rebuttable presumption that the effect of a measure or practice is discriminatory, the burden then shifts to the respondent State, which must show that the difference in treatment is not discriminatory. ${ }^{25}$ [Emphasis added]

Consequently, reliable and significant statistical evidence can be used to create a presumption that conduct in an individual case against an applicant was based on race. The term 'significant' has a specific meaning in the context of statistical evidence. It is used to mean that the evidence has reached a threshold where, in pragmatic terms, a presumption of equal treatment (ie the irrelevance of race) can no longer be made. A statistical finding is generally considered 'significant' if it has a pvalue of $<0.05$. A p value "is defined as the probability of a result as extreme as that obtained, given that the null hypothesis is true" (Gordon 2012a, para. 23).

The reliability or 'validity' of statistical evidence is case dependent and can depend on a range of factors including the use of controls, treatment of missing data and reproducibility. 'Validity' and 'significance' are different to 'relevance'. Some of these concepts were discussed by the Court of Justice of European Communities, quoting from Regina v. Secretary of State for Employment, ex parte Nicole Seymour-Smith and Laura Perez (judgment of 9 February 1999, CJEC):

... the Commission proposes a 'statistically significant' test, whereby statistics must form an adequate basis of comparison and the national court must ensure that they are not distorted by factors specific to the case. The existence of statistically significant evidence is enough to establish disproportionate impact and pass the onus to the author of the allegedly discriminatory measure....It is also for the national court to assess whether the statistics concerning the situation ... are valid and can be taken into account, that is to say, whether they cover enough individuals, whether they illustrate purely fortuitous or shortterm phenomena, and whether, in general, they appear to be significant. 26 [emphasis added]

In making use of statistical evidence, a court is likely to examine its significance (usually $\mathrm{p}<0.05$ ), its reliability (that it is reproducible and otherwise valid) and its relevance to the issue at stake. In the Canadian case of Kelly v. Palazzo $(2005)^{27}$ the plaintiff attempted to use statistical evidence to prove racial profiling existed in the process of selecting who would be searched at an airport, however, because of the small number of

\footnotetext{
${ }^{24}$ Evidence Act 2008 (Vic) s 140(2).

${ }^{25}$ DH v The Czech Republic (European Court of Human Rights, Grand Chamber Judgement, 13 November 2007$) 188,189$.

${ }^{26}$ D.H. v. The Czech Republic (n 25) 88.

${ }^{27}$ Kelly v. Palazzo 2005 CanLII 46398 (ON SC).
} 
searches examined in the data used in the proceedings, and its alleged lack of statistical significance the data was not admitted into evidence.

Given the power imbalance between the state and the individual, it is not always possible for applicants to obtain the best statistical data. In Regina $v$. Immigration Officer at Prague Airport and another ex parte European Roma Rights Centre and others (House of Lords, 2004) six people (the applicants) were refused entry into the UK. They argued that the decision to investigate and refuse them entry was discriminatory. In this case, the applicants, through the work of the European Roma Rights Centre were able to provide some statistical evidence, but the respondents (Immigration officials at the Prague airport) did not. The House of Lords stated:

The officers did not make any record of the ethnic origin of the people they interviewed. The respondents cannot therefore provide us with figures of how many from each group were interviewed, for how long.... what it also shows is that no formal steps were being taken to gather the information which might have helped ensure that this high-risk operation was not being conducted in a discriminatory manner. It also means that the only information available is that supplied by the claimants, and in particular the ERRC which was attempting to monitor the operation. The respondents can cast doubt on the reliability of this, but they cannot contradict it or provide more reliable information themselves. ... ${ }^{28}[\mathrm{em}-$ phasis added]

This case indicates that where it would have been possible for officials to collect evidence, but they fail to do so, courts can be prepared to draw adverse inferences against them and take into account data provided from other sources. This is an important issue in a case currently before the European Court of Human Rights where the applicants, but not police, have provided statistical evidence. In Seydi \& Ors v France, filed on 8 May 2016, six Black French applicants, using data collected by the Open Justice Initiative (Goris 2009), are arguing that the stops by police of them were discriminatory on 6 grounds: a) that the law is not precise enough to prevent discriminatory stops; b) that there is statistical evidence of structural disproportionality in who is stopped; c) the statistical evidence shifts the burden of proof to the police to explain why the stops were not discriminatory; d) there was no justification for the stops; e) they are not proportionate for crime control reasons; and f) that there is a positive obligation on the state to collect data on stops to uncover discrimination (Open Society Justice Initiative 2016, p. 23).

Prima facie evidence of discrimination is frequently founded on comparative evidence. In Peel Law Association $v$ Pieters [2013] ONCA 396 a librarian's questioning of the status of three Black lawyers in the absence of questions of White lawyers created a prima facie case of racial discrimination. In Phipps v Shaw (2011) ONCA 155 , the police suspicion of a Black but not White letter carrier created a prima facie case of racial profiling (Sheppard and Chabot 2018, p. 17-18). DH v Czech Republic provides support for the proposition that statistical evidence can substitute for providing direct comparative evidence in creating a prima facie case of discrimination.

In the next three sections (paragraphs 3.3.1, 3.3.2 and 3.3.3) I will examine the way statistical evidence has been used to attempt to shift the burden of proof in cases involving racial profiling by police in England, the US and Canada. I will show that while the use of such data to establish a prima facie case is advanced in the US, it is open, but undecided in Canada and unlikely to be decided soon in England. These differences can only partly be explained by the availability of data. As we will see, they are more likely to reflect racial and structural biases in the legal profession.

\subsubsection{THE USE OF STATISTICAL EVIDENCE TO SHIFT THE BURDEN OF PROOF IN THE UK}

An attempt was made to rely on $D H v$ The Czech Republic to introduce statistical evidence to shift the burden of

\footnotetext{
${ }^{28}$ European Roma Rights Centre \& Ors, R (on the application of) v Immigration Officer at Prague Airport \& Anor [2004] UKHL 55 (9 December 2004), [91].
} 
proof in the 2012 UK case of Roberts. ${ }^{29}$ In Roberts, a Black woman was searched by police for weapons on a bus after failing to pay for the trip and not providing evidence of her name and address. The Court declined to admit statistical evidence of the racially discriminatory use of the weapons search power on the basis that the evidence was disputed by the state, and 'witnesses who speak to those figures'30 had not been called and crossexamined. It appears that the argument to admit expert evidence on the data was made too late in the proceedings (in the first appeal). When applicants fail to squarely allege racial discrimination in proceedings at first instance, Courts in Australia and England often avoid adjudicating it. 31

Roberts was appealed, unsuccessfully, to the Supreme Court where Deputy President Lady Hale gave the leading judgement. In her decision, Lady Hale made assertions of fact against Black and minority ethnic people without providing statistical evidence. For example she said: "It must be borne in mind that many of these gangs are largely composed of young people from Black and minority ethnic groups." 32 Research evidence shows that being listed on a gang database in the UK has little to do with a person's involvement in crime, but everything to do with race (Williams and Clarke 2016). It is ironic that the Court made stereotypical statements against racial groups without statistical proof, while was reluctant to accept the role of statistics in establishing the social context for making findings of racial discrimination against police and state actors.

In the case of Gillan $v$ Commissioner of Police for the Metropolis \& Anor [2006] UKHL 12 (8 March 2006) two White people attending an arms fair protest (one of whom was a journalist) were searched for weapons under the Terrorism Act 2000. The House of Lords decided that these searches did not infringe human rights. While the decision was overturned later in the European Court of Human Rights, Lord Brown from the House of Lords, stated in relation to the power of police to undertake random searches under the Terrorism Act 2000:

Ethnic origin accordingly can and properly should be taken into account in deciding whether and whom to stop and search provided always that the power is used sensitively and the selection is made for reasons connected with the perceived terrorist threat and not on grounds of racial discrimination. ${ }^{33}$

While attempting to do otherwise, Lord Brown's statement effectively authorises arbitrary searches on the grounds of stereotypes, including racial ones. Highlighting a difference between the jurisdictions, his Lordship's statement sits in sharp contrast with comments in 2013 from US Judge Scheilder in Floyd:

While a person's race may be important if it fits the description of a particular crime suspect, it is impermissible to subject all members of a racially defined group to heightened police enforcement because some members of that group appear more frequently in criminal complaints. ${ }^{34}$

Over the last 25 years, as a consequence of legislative requirements to collect data, England and Wales have amassed a huge quantity of quality data and scholarship on the disproportionate use of stop and search by police against Black and minority ethnic communities (Bowling and Phillips 2007, 941). As a consequence of

\footnotetext{
${ }^{29}$ Roberts, R (on the Application of) v The Commissioner of the Metropolitan Police [2012] EWHC 1977 (Admin) (17 July 2012 ).

${ }^{30}$ United Kingdom: Roberts, R (on the Application of) v The Commissioner of the Metropolitan Police [2012] EWHC 1977 (Admin) (17 July 2012)' [51].

31 See for Prior v Mole [2017] HCA 10. It is worth noting that in Canada courts have permitted arguments about racial profiling on appeal despite the absence of argument in earlier proceedings: conversation with David Tanovich on 22 August 2020: R. v. Richards 1999 CanLII 1602 (ON CA).

32 'Roberts, R (on the Application of) v The Commissioner of Police of the Metropolis \& Ors [2014] EWCA Civ 69 (04 February 2014)' 41 <https://www.bailii.org/ew/cases/EWCA/Civ/2014/69.html>.

33 Gillan, $R$ (on the application of) $v$. Commissioner of Police for the Metropolis \& Anor [2006] UKHL 12 (8 March 2006) per Lord Brown of Eaton-Under-Heyward [81].

${ }^{34}$ Floyd $v$ The City of New York, 959 F. Supp. 2d 540, 2013, 82, 83.
} 
this data, it makes sense to assume that English caselaw would be replete with examples of its use in proving racial discrimination against police officers. Conversely, however, and for at least three reasons, the UK courts have avoided the issue and this is unlikely to be addressed any time soon. Firstly, and as the cases above reveal, there exists prejudice in some of the UK's judges (Moeckli 2007). These decisions reveal the strength of the racially biased and demonstrably inaccurate gangs narrative that has gained media and social traction (Williams and Clarke 2016). Sarah Flanagan, a leading police misconduct lawyer based in London, puts it this way:

Discrimination cases are notoriously difficult to get through the courts because a lot of white judges come from, you know, wealthy backgrounds, and they believe that a lot of gang members are black. It's inconceivable to think that it's otherwise. You have to advise a client of that, you know, these are very difficult cases to get through. You're talking about judges from a white area who feel uncomfortable if they were told to walk through an area that's largely a black population or mixed population. They're not going to feel comfortable [if] they've never walked in those areas before. They don't know what to do. So when they see a black kid in front of them, they see a stereotype....They see them with their jeans hanging down, they see the classic stereotype, you're an angry, young person who's fed up, a young person who is, again, saying that they've been discriminated against. ${ }^{35}$

Secondly, structural issues, such as the absence of high costs awards to lawyers, the inadequacy of public funding, costs risks to applicants and settlement pressures, have made the bringing of a discrimination claim in the UK all but impossible. ${ }^{36}$ This is despite the presence of direct and indirect discrimination provisions, and a legislative shift in the burden of proof in the Equality Act 2010. Thirdly, the police have "learned to defend themselves from the use of data." 37 In Roberts, the courts required uncontested data to make findings, and yet would not permit the plaintiff to call experts to resolve the contest. While the data on disproportionality is largely uncontroversial, questions have been raised by some about the inadequacy of benchmarks used to demonstrate disproportionality (Miller and MVA 2000, Fridell 2004). For example, Joel Miller argues that disproportionality should be benchmarked against 'available populations' rather than the census (Miller and MVA 2000). Others have argued that benchmarking data against the 'available population' can entrench inequality where the decision about which 'available population' to target is itself biased by race (see Hopkins 2017, pp. 26-39). This debate has not been judicially resolved in the UK.

\subsubsection{THE USE OF STATISTICS TO SHIFT THE BURDEN OF PROOF IN THE US}

The use of statistical evidence to shift the burden of proof is advanced in the US. Statistical evidence has played a central role in a number of US racial profiling decisions. In State v. Soto, 734 A.2d 350 (N.J. Super. Ct. Law Div.1996) statistical evidence of a pattern of disproportionate stops of African-American drivers, benchmarked against the driving population on those roads, was used by the Court to find a prima facie case that the stops of 17 African-American drivers, caught carrying drugs, were racially discriminatory. While the police attempted, unsuccessfully to challenge the data, they didn't provide evidence to rebut the prima facie finding of the Court and the judge ruled to exclude the evidence of drug possession. Statistical evidence was used in a similar way in Wilkins v Maryland State Police MJG 93-468 (D.Md) (Lamberth and Buckman 2001). The data used by the statisticians in these cases was partly obtained through discovery in the litigation process itself and partly through field research. In 2013, NYPD data on stop, question and frisk became publicly available as a result of litigation. ${ }^{38}$ The respondent disputed the relevance and validity of the use of data

\footnotetext{
${ }^{35}$ Interview with Sarah Flanagan, 5 May 2020 (UNSW HREC HC180500).

${ }^{36}$ Ibid.

${ }^{37}$ Interview with Michael Shiner, 20 March 2020 (UNSW HREC HC180500).

${ }^{38} \mathrm{https}$ ///data.cityofnewyork.us/Public-Safety/The-Stop-Question-and-Frisk-Data/ftxv-d5ix
} 
analysed by the applicants' expert in Floyd $v$ The City of New York. ${ }^{39}$ In Floyd, the City argued that police should be focussed on stopping and frisking Black people because of the rate at which Black people are named as suspects in victim accounts. ${ }^{40}$ Thus the benchmark should be 'criminal suspects' not the local population. Judge Scheilder cut through this defence decisively by concluding on the statistical evidence that the stop and frisk regime was in practice focussed on stopping innocent people not people named in suspect descriptions. ${ }^{41}$

In Floyd, statistical evidence showed that Black and Hispanic New Yorkers were more likely to be stopped, searched, arrested, and have force used against them, were less likely to be found with weapons or contraband and were less likely to be subject to law enforcement action as a consequence of the stop. ${ }^{42}$ In Floyd, the Court examined whether the stops violated the Fourth Amendment (probable cause) and 14th Amendment (equal treatment) of the US Constitution. The judge found that the New York Police Department's overall practice of stop and frisk violated the $14^{\text {th }}$ amendment. This is effectively a finding of institutional racism. However, while the Judge found that 9 of 18 stops were unconstitutional, she did not distinguish, at an individual level, whether it was a Fourth or Fourteenth Amendment violation that made them so.

\subsubsection{THE USE OF STATISTICS TO SHIFT THE BURDEN OF PROOF IN CANADA}

The role of statistical data in creating a prima facie case of discrimination remains undecided in Canada. However, in 2006, the Canadian Supreme Court in Peart expressed an openness to shifting the burden of proof. The Court stated: "Perhaps a more frequently significant consideration in the fixing of the burdens of proof is the judicial estimate of the probabilities of the situation. The risk of failure of proof may be placed upon the party who contends that the more unusual event has occurred." 43 The Supreme Court in Peart accepted that the party alleging the more unusual event should have the burden of proof. ${ }^{44}$ However, because the Court heard no evidence to prove whether racial profiling was or was not the more unusual event, the Court concluded that there were no grounds to reverse the onus of proof. ${ }^{45}$

Since Peart was decided, data indicating the prevalence of racial profiling across Canadian police forces is emerging (Foster et al 2016, p. 72; Wortley 2019, p. 186). Unlike in England and Wales, where the police are obligated to release regular ethnicity data on stop and search, in Canada this data is being assembled primarily through social science techniques such as surveys (Wortley and Owusu-Bempah 2011), and analysis of data retrieved from the police through agreements with Human Rights Commissions (Foster et al 2016; Wortley 2019; Wortley and Jung 2020, p. 121). Canadian racial profiling expert and litigator David Tanovich argues it is time for the courts to revisit the question of who bears the burden of proof in racial profiling cases. He argues that in jurisdictions where data reveals the presence of racial profiling, the burden should be placed on police to prove otherwise (Tanovich 2018). These arguments reveal how critically important publicly available data is in establishing racial discrimination claims in individual cases. I will now consider the application of these three evidentiary principles to the two Australian cases I described in the introduction.

\section{APPLICATION TO AUSTRALIAN CASE}

\subsection{HAILE-MICHAEL}

Because the Haile-Michael proceedings settled we do not know to what use the Federal Court may have put the statistics the litigation generated. The data obtained

\footnotetext{
${ }^{39}$ Floyd $v$ The City of New York, 959 F. Supp. 2d 540, 2013.

40 Ibid, 51, 52.

41 'Floyd v The City of New York, 959 F.Supp.2d 540, 2013 WL 4046209.' (n 13) 9.

${ }^{42}$ Ibid.

${ }^{43}$ Peart v. Peel Regional Police Services, 2006 CanLII 37566 (ON CA) [144,145] quoting McCormick, 475-76.

${ }^{44}$ Ibid [94].

${ }^{45}$ Ibid [146].
} 
in Haile-Michael was analysed by Professor Ian Gordon, who examined field contact reports completed by police in Flemington and North Melbourne between 20052008. He found that African/Middle Eastern youth were 2.53 times more likely to be stopped for a field contact by police than their proportion in the population would predict (Hopkins 2017, p. 27). In this case, the figure 2.53 is a risk ratio. ${ }^{46}$ It compares the rate of a group experiencing being stopped for a field contact compared with their proportion in the population (Gordon 2012a, para. 108). This finding had a $p$-value of $<0.001$ (Gordon 2012a, p. 23). The p-value demonstrates that the evidence is very strong that there is difference in the rate at which police stop African/Middle Eastern youth compared to other youths. Had the Haile-Michael case proceeded, we can assume that the six applicants would have led evidence of their treatment by police. We can also assume that they would have led evidence about the social context of their treatment. This would have included the statistical evidence of the significant racial disparity in police stops of African/Middle Eastern youths between 2005-2008 described above. It would have also included the substantial history of police complaints filed in the area, the evidence about an ethical health check of the Flemington Police Station conducted in 2006 (Hopkins 2007) and the wording of an operational order that directed police to focus on African youth for a one-month period (see a detailed discussion of this order in Hopkins 2021). We can further assume that the police would have led contradicting evidence. Drawing on the evidentiary strategies outlined in this paper, the following steps set out the arguments the applicants may have presented.

The starting point for the applicants may have been to argue that the social context evidence demonstrated that racial profiling was in fact the standard operational practice of the police: it was the lived experience that defined all contact between the parties. The second argument the applicants may have put to the Court was that the documented pattern of targeted conduct over four years, founded a prima facie case that the stops were racially discriminatory. This would then shift the burden to the police to prove that their contact with the applicants was not, in part, based on race. The reasons the police offered for contact with the applicants, would then be assessed through the lens of the social context evidence to assess credibility and to determine if they correspond with racial profiling or were objectively justified. If the Court were not persuaded to shift the burden of proof, the applicants would argue, in the alternative, that the Court could use the evidence of the documented pattern of stops and the operationally ordered police focus on African youths and other social context evidence, to lower the cogency of the evidence required for the applicants to prove on the balance of probabilities that the stops they experienced were racially discriminatory. Again, the facts would be analysed, in the context of the statistical and other social context evidence to assess whether they correspond with racial profiling.

\subsection{TANYA DAY}

In Tanya Day's inquest, social context evidence of racial discrimination was permitted, but not statistical evidence. For the purpose of this comment, I assume the statistical evidence presented was valid and statistically significant. The impact of the Coroner's refusal to consider statistical evidence can be seen by comparing her findings at two points in the inquest.

First, drawing on social context evidence, the Coroner found that a rail officer was racially biased in deciding to call the police rather than pursue other options when he discovered Tanya sleeping in a train carriage. The Coroner found that this was the first time the rail officer had made a decision to call the police in relation to a sleeping passenger, despite encountering one three times a week. She found that his decision to characterise Tanya as 'unruly', (Finding into the Death of Tanya Day, [225]) triggering the call to police, diverged from

\footnotetext{
${ }^{46}$ Risk ratios tell us information about the substantive difference between the groups, but on their own, do not provide information about the strength of the evidence revealing that difference.
} 
his treatment of other sleeping passengers and was racially biased. (Finding into the Death of Tanya Day, [213]-[225])

Secondly, and in contrast, the Coroner did not use social context evidence (in this case statistics) in assessing the decision-making of the police. The Coroner heard evidence that the police had responded very differently towards Tanya in exploring alternatives to police detention than they had towards a 'heavily intoxicated' (Finding into the Death of Tanya Day, [334] [341]) woman they encountered shortly after Tanya's arrest. The Coroner explained that the difference in treatment was the result of the police having an address for the second woman. There were, however, a number of alternatives to police detention for Tanya that the police did not pursue. If the Coroner had permitted the use of statistics that showed Aboriginal women were more likely to be detained at the police station for being drunk than other women, and more likely to be identified as being drunk than other women, to play a part in comparing the treatment of Tanya to the other woman, this, in conjunction with the police failure to pursue alternatives, may have been sufficient to find on the balance of probabilities that race was a factor in the police behaviour. Recall race only needs to be a factor, not the only factor for s 9 of the RDA to apply. If the Coroner had used these statistics to contextualise why a 'community type of response' (Finding into the Death of Tanya Day, [329]) was offered for the second woman, and not Tanya, she may have concluded that race played a part in the police decision-making (consciously or otherwise). The statistics may have permitted the Coroner to understand how the police behaviours in this case fit within a pattern of conduct that corresponds to racial discrimination and interpret them in this light. Furthermore, the statistics may have been used to lower the cogency of evidence the Coroner required to be satisfied that the police conduct amounted to racial discrimination. They may have enabled the Coroner to move beyond the otherwise narrow and language-based construction of discrimination she used in this case. ${ }^{47}$

\section{CONCLUSION}

Racial discrimination is framed constitutionally in the US and legislatively in England, Canada and Australia in a way that presumes it to be an isolated individual experience, and yet statistical and other social science evidence demonstrates its institutional basis. To bridge this gap, the courts need to be willing to use statistical and social science data to draw inferences of racial discrimination in individual cases. While Wotton demonstrates the $R D A$ 's potential in identifying institutionally racist policing operations against Indigenous communities it did not make findings of racial discrimination against individual officers. ${ }^{48}$ I have argued in this paper that there are three important ways for courts to counter limitations in legislative and constitutional framing by using statistical and other social science evidence in specific cases. Evidence of institutional racism demonstrated through statistical and other forms of evidence offers the opportunity for courts to use common law devises to lower the standard of proof, to shift the burden of proof and to assess credibility of, contextualise, or understand other evidence. These devises can assist in identifying individual instances of racism while simultaneously acknowledging the way racism is authorised through institutional practices.

One possible explanation for why statistical data remains unusual in proving racial discrimination in Australia is the relative absence of data collection across Australia's criminal justice, health and education systems on the salience of race in the outcomes these institutions produce. This contrasts with England, US and Canada. However, when statistical evidence is produced in Australia, stark discrepancies are revealed (Barnes 2019; Sentas and Pandolfini 2018; Hopkins 2021). Data collection on the race of those the police stop, question, search, fine, use force against, prosecute, caution, ne-

\footnotetext{
${ }^{47} \mathrm{I}$ am indebted to one of my anonymous reviewers for this observation.

${ }^{48}$ Contrast to Barnes v Northern Territory Police \& Anor [2013] FCCA 30 (n 32) when the Court used social context evidence to make a finding of racial discrimination in an individual case.
} 
glect, fail to assist and imprison is critical to understanding the extent of racial discrimination in Australia. When statistics of institutional racism are produced, they can and should be used by courts to assist in making findings of racism in individual cases. This analysis has revealed however, that it is not only the availability of data that is required for courts to adopt these strategies. A willingness to work with statistics and other social context data may require a shift in the attitudes and structural barriers that can limit lawyers and judges in considering cases involving race discrimination.

\section{REFERENCES}

1. Agarwal, R., Lalani, F., and Boutilier, M. 2018. "Lessons from Latif: Guidance on the Use of Social Science Expert Evidence in Discrimination Cases." Canadian Bar Review, 96 (1): 36-56.

2. Barnes, G. 2019. "Lifetime Traffic Penalty Comparison, Briefing Note." WA Police, released under FOI to Guardian Australia, 13 February 2019.

3. Baumgartner, F., Epp, D., and Shoub, K. 2018. Suspect Citizens, What 20 Million Traffic Stops Tell Us about Policing and Race. Cambridge, UK. Cambridge University Press.

4. Boon-Kuo, L., Brodie, A., Keene-McCann, J., Sentas, V., and Weber, L. 2020. "Policing biosecurity: police enforcement of special measures in New South Wales and Victoria during the COVID-19 pandemic." Current Issues in Criminal Justice. 33 (1): 76-88.

5. Bonilla-Silva, E. 2014. Racism without Racists. Maryland USA, Rowman and Littlefield Publishers Inc, Fourth Ed.

6. Bowling, B. and Phillips, C. 2007. "Disproportionate and Discriminatory: Reviewing the Evidence on Police Stop and Search." Modern Law Review, 70 (6): 936-961.

7. Burtis, M., Gelbach, J., and Kobayashi, B. 2017. "Error Costs, Legal Standards of Proof and Statistical Significance." Faculty Scholarship 1754: 1-40.

8. Carmichael, S. and Hamilton, C. 1967. Black Power, The Politics of Liberation. NY, USA: Random House.
9. de Plevitz, L. 2003. "Briginshaw 'Standard of Proof' in Anti-Discrimination Law: 'Pointing with a Wavering Finger.'" Melbourne University Law Review, 27 (2): 308-333.

10. Dixon, D., Bottomley, A. K., Coleman, C. A., Gill, M., and Wall, D. 1989. "Rules and Reality in the Construction and Regulation of Police Suspicion." International Journal of the Sociology of Law, 17: 185-206.

11. Dunn, C. and Shames, M. 2019. Stop and Frisk in the de Blasio Era. New York Civil Liberties Union, March 2019.

12. Epp, C. R., Maynard-Moody, S., and Haider-Markel, D. 2014 Pulled over: How Police Stops Define Race and Citizenship. Chicago, US: University of Chicago Press.

13. Faruqi, 0. 2020. "Compliance Fines under the Microscope". The Saturday Paper, online, 18 April https://www.thesaturdaypaper.com.au/ne ws/health/2020/04/18/compliance-finesunder-the-microscope/15871320009710

14. Foster, L., Jacobs, L., and Siu, B. 2016. "Race Data and Traffic Stops in Ottawa, 2013-2015 : A Report on Ottawa and the Police Districts." Submitted to the Ottawa Police Board.

15. Fridell, L. 2004. "By the Numbers: A Guide for Analyzing Race Data from Vehicle Stops." Police Executive Research Forum.

16. Gordon, I. 2012a. First Report of Professor Gordon (Redacted) Hail-Michael v Konstantinidis VID 969 of 2010, 11 September 2012, 23.

17. Gordon, I. 2012b. 2nd Expert Report of Ian Gordon, Filed in Haile-Michael \& Ors in the Federal Court of Australia on 13/11/2012.

18. Goris, I. 2009. Profiling Minorities: A Study of Stop and Search Practices in Paris (Open Justice Society).

https://www.justiceinitiative.org/publications/profiling-minorities-study-stop-andsearch-practices-paris Accessed 115/11/2020

19. Hall, Stuart. 1999. "From Scarman to Stephen Lawrence." History Workshop Journal, 48: 187197. 
20. Hopkins, T. 2007. "Complaints against police behavior in Flemington." Alternative Law Journal, 32, (1): 32-36.

21. Hopkins, T. 2017. Monitoring Racial Profiling Introducing a Scheme to Prevent Unlawful Stops and Searches by Victoria Police A Report of the Police Stop Data Working Group. Police Stop Data Working Group.

22. Tamar Hopkins (2021) "Litigating racial profiling: examining the evidence for institutional racial profiling by police against African-Australians in Flemington, Victoria" Australian Journal of Human Rights, 26 (2): 209-226, DOI: 10.1080/1323238X.2021.1872132

23. Lamberth, J. and Buckman, W. 2001. "Challenging Racial Profiles: Attacking Jim Crow on the Interstate". Rutgers Race and the Law Review, 3: 83115.

24. Marlow, A. and Loveday, B. 2000. "Race, Policing and the Need for Leadership" in After Macpherson, Policing After the Stephen Lawrence Inquiry. Dorset, UK: Russell House Publishing.

25. Miller, J. and MVA. 2000. Profiling Populations Available for Stops and Searches. UK: Home Office.

26. Moeckli, Daniel. 2007. "Stop and Search Under the Terrorism Act 2000: A Comment on R (Gillan) v Commissioner of Police for the Metropolis". The Modern Law Review, 70 (4): 659-670.

27. Open Society Justice Initiative. 2016. "Seydi and Others V France: Application". 8 May 2016, https://www.justiceinitiative.org/litigation/seydi-and-others-v-france

28. Sentas, V. 2014. Traces of Terror Counter-Terrorism Law, Policing, and Race. Oxford, UK: Oxford University Press.

29. Sentas, V. and Pandolfini, C. 2017. Policing Young People in NSW A Study of the Suspect Targeting Management Plan, NSW: Youth Justice Coalition.

30. Sheppard, C. and Chabot, M. L. 2018. "Obstacles to Crossing the Discrimination Threshold: Connecting Individual Exclusion to Group-Based Inequalities." Canadian Bar Review, 96 (1): 1-35.
31. Shiner, M. et al. 2008, The Colour of Injustice, 'Race', Drugs and Law Enforcement in England and Wales, Stopwatch, Release.

32. Shiner, M. and Thornbury, P. 2019. Regulating Police Stop and Search: An Evaluation of the Northamptonshire Police Reasonable Grounds Panel, Open Society Justice Initiative.

33. Siu, B. 2017. "Defining the Concept of Racial Profiling: A Discussion". Canadian Diversity, 14(1): 11-13.

34. Skolnick, J. H. and Fyfe, J.J. 1993. Above the Law, Police and the Excessive Use of Force New York: The Free Press.

35. Stuart, F. 2016. Down, out and under Arrest. Policing and Everyday Life in Skid Row. Chicago, USA: University of Chicago Press.

36. Tanovich, D. M. (2017). Applying the racial profiling correspondence test. Criminal Law Quarterly, 64(3-4): 359-383.

37. Taylor, K-Y. 2016. From \#BlackLivesMatter to Black Liberation. Chicago, USA: Haymarket Books.

38. Van Maanen, J. 1978. 'The Asshole' in Tim Newburn (ed) 2005, Policing, Key Readings. Oxfordshire, UK: Routledge.

39. Weber, L. 2020. You're Going to Be in the System Forever: Policing, Risk and Belonging in Greater Dandenong. Melbourne: Monash University.

40. Williams, P. and Clarke B. 2016. Dangerous Associations: Joint Enterprise, Gangs and Racism, Centre for Crime and Justice Studies.

41. Williams, P. 2018. Being Matrixed: The (Over) Policing of Gang Suspects in London London, UK: StopWatch.

42. Wortley, S. and Owusu-Bempah, A. 2011. "The Usual Suspects: Police Stop and Search Practices in Canada". Policing and Society, 21 (4): 395-407.

43. Wortley, S. 2019. Halifax, Nova Scotia: Street Checks Report (Nova Scotia Human Rights Commission, March 2019) https://humanrights.novascotia.ca/sites/default/files/editor-uploads/halifax street checks report march 2019 0.pdf 
44. Wortley, S. and Jung, M. 2020. Racial Disparity in Arrests and Charges Toronto, Ontario Human Rights Commission.

\section{Legislation}

Australia

Charter of Human Rights and Responsibilities Act 2006 (Vic), ss10, 12, 13, 16, 21, 22.

Evidence Act 2008 (Vic) s140(2)

Racial Discrimination Act 1975 (Cth) ss 9, 18

Other

United Kingdom: Equality Act 2010

US Constitution Art 4, 14

\section{Case law}

Australia

Barnes v Northern Territory Police \& Anor [2013] FCCA 30.

Briginshaw v Briginshaw (1938) 60 CLR 336 (30 June 1938)

Department of Health $v$ Arumugan [1988] VR 319.

Ejueyitsi v Commissioner of Police (Western Australia) (No2) [2015] FCCA 494.

Ruling on Application Regarding Scope of the Inquest Tanya Day (Coroners Court of Victoria, Melbourne, 25 June 2019)

Finding into the death of Tanya Day (Coroners Court of Victoria, 9 April 2020)

Haile-Michael v Konstantindis VID 969/2010 Federal Court of Australia, Melbourne. Settled 18 February 2013

Prior v Mole [2017] HCA 10

Neat Holdings Pty Ltd $v$ Karajan Holdings Pty Ltd (1992) 110 ALR 449

Wotton $v$ The State of Queensland (No 5) [2016] FCA 1457.

Other

Canada: Peart v. Peel Regional Police Services, 2006 CanLII 37566 (ON CA)

Canada: $R v$ Brown [2003] OJ No 1251 (2003).

Canada: $R v$ Dudhi [2019] ONCA 665 (Ontario Court of Appeal, 14 June 2017).
Canada: Kelly v. Palazzo, 2005 CanLII 46398 (ON SC). Canada: Nassiah v. Peel (Regional Municipality) Services Board, 2007 HRTO 14.

Canada: R. v. Richards, 1999 CanLII 1602 (ON CA).

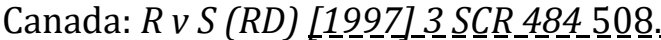

United States: Floyd $v$ The City of New York, 959 F.Supp.2d 540, 2013 WL 4046209.

United States: State v. Soto, 734 A.2d 350 (N.J. Super. Ct. Law Div.1996).

United States: Wilkins v Maryland State Police MJG 93468 (D.Md).

United Kingdom: Gillan, $R$ (on the application of) $v$. Commissioner of Police for the Metropolis \& Anor [2006] UKHL 12 (8 March 2006) per Lord Brown of Eaton-Under-Heyward [81].

United Kingdom: Roberts, R (on the Application of) $\mathrm{v}$ The Commissioner of the Metropolitan Police [2012] EWHC 1977 (Admin) (17 July 2012)' https://www.bailii.org/ew/cases/EWHC/Admin/2012/1977.html.

United Kingdom: Roberts, R (on the Application of) $\mathrm{v}$ The Commissioner of Police of the Metropolis \& Ors [2014] EWCA Civ 69 (04 February 2014) <https://www.bailii.org/ew/cases/EWCA/Civ/2 014/69.html>.

Roberts, R (on the application of) $v$ Commissioner of Police of the Metropolis and another [2015] UKSC 79 (17 December 2015)

United Kingdom: Regina v. Immigration Officer at Prague Airport and Another, Ex parte European Roma Rights Centre and Others, [2004] UKHL 55, United Kingdom: House of Lords (Judicial Committee), 9 December 2004, available at: https://www.refworld.org/cases,GBR HL,41c17ebf4.html [accessed 17 December 2020].

European Court of Human Rights: D.H. v. The Czech Republic, Grand Chamber Judgment of 13 November 2007.

United Nations: UN General Assembly, International Convention on the Elimination of All Forms of Racial Discrimination, 21 December 1965, United Nations, Treaty Series, vol. 660, p. 195, available at: 
http://www.refworld.org/docid/3ae6b394

0.html [accessed 3 October 2018], Art 5

United Nations: UN General Assembly, International Covenant on Civil and Political Rights, 16 December 1966, United Nations, Treaty Series, vol. 999, p. 171. 